\title{
Detection of QTLs for grain protein content in durum wheat
}

\section{A. Blanco $\cdot$ R. Simeone $\cdot$ A. Gadaleta}

Published online: 20 June 2006

(C) Springer-Verlag 2006

\section{Theor Appl Genet (2006) 112:1195-1204.}

DOI: 10.1007/s00122-006-0221-6

The authors regret that the legends accompanying

Figs. 1 and 2 were not fully correct. The figures are reproduced here with the correct legends.

The online version of the original article can be found at http:// dx.doi.org/10.1007/s00122-006-0221-6

A. Blanco $(\bowtie) \cdot$ R. Simeone $\cdot$ A. Gadaleta

Department of Environmental and Agro-Forestry Biology and Chemistry, University of Bari, Via Amendola, 165/A, 70126 Bari, Italy

e-mail: blanco@agr.uniba.it 
Fig. 1 Frequency distributions of grain protein content values of three genotypes based on $X c f a 2164-2 A$ in a F3 progenies grown at Valenzano in 2001 and b, c F4 progenies grown at Valenzano and Gaudiano in 2002, respectively. 1 Marker allele from cv. Latino (low grain protein content); 2 marker allele from 3BIL-85 (high grain protein content)
Genotypes $\square 11 \quad \square 12 \quad \square 22$

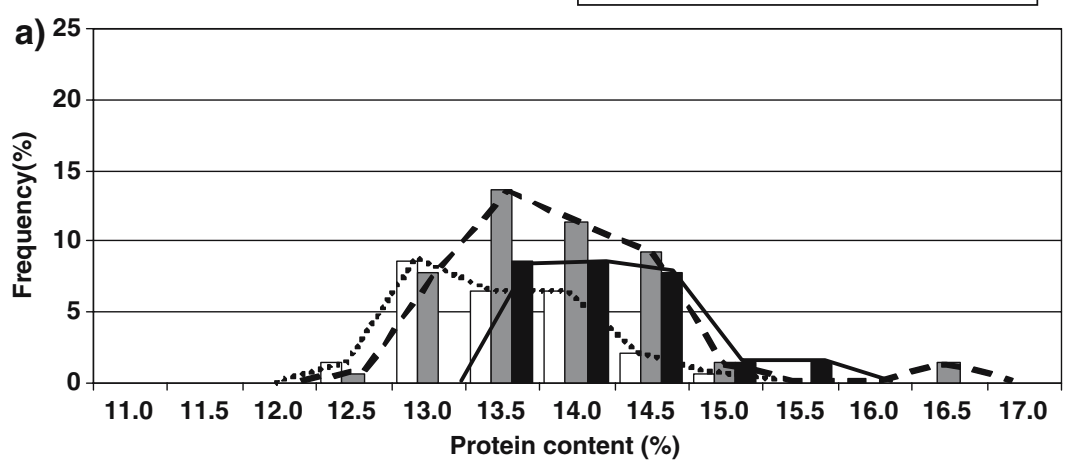

Genotypes $\square 11 \quad \square 12 \quad \square 22$



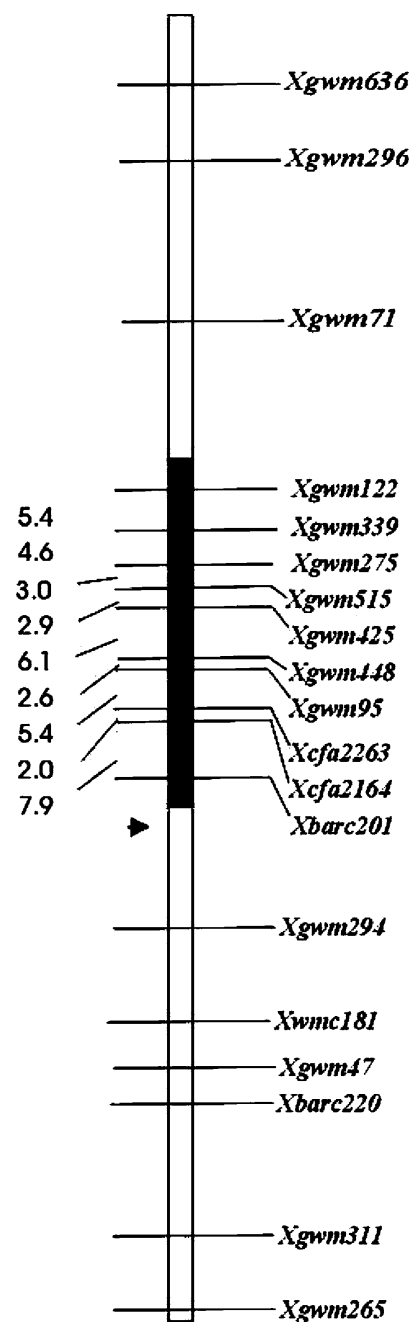

Fig. 2 Linkage map of the $2 \mathrm{~A}$ chromosome segment introgressed from var. dicoccoides in the backross inbred line 3BIL-85 (black region). Map distances (cM) and microsatellite markers significantly associated to grain protein content are shown on the left and right sides. The centromere (filled arrow) and the introgressed segment were positioned according to previously published maps (Roder et al. 1998; Blanco et al. 2004) 